\title{
From Outsiders to Insiders: A Civil Society Perspective on EU Financial Reforms*
}

\author{
LISA KASTNER \\ Max Planck Sciences Po Center on Coping with Instability in Market Societies
}

\begin{abstract}
This article examines the role of non-financial interest groups in EU financial regulatory decisionmaking. While regulatory capture theories clearly helped identify the causes for the incrementality in spite of the major shock the 2008 crisis had caused, this article will consider a range of regulatory policy initiatives that do not neatly conform with this theory. I examine the extent to which nonfinancial groups are able to have their preferences met in the making of three different consumer policies: the Mortgage Credit Directive (MCD), stricter regulations of retail investment products (PRIPs/KID) and the reform of EU level supervisory structures. By employing a process-tracing approach based on qualitative interviews to analyze political responses to the 2008 financial crisis, the article demonstrates that newly mobilized groups could translate key advocacy goals into policy by deploying counter-expertise and co-operating with policy-makers in some cases but not in others.
\end{abstract}

Keywords: consumer finance protection; financial crisis; interest groups; lobbying

\section{Introduction}

Similarly to the US reaction to the financial crisis of 2008, the EU agreed on a series of reform proposals that significantly altered the regulatory architecture of European financial regulation and deepened the single market in financial services. Although there is no overarching initiative in the EU that would be comparable to the Dodd-Frank Act, the European Commission brought forward more than 40 measures to reform its financial architecture in response to the crisis (Moloney,2012). Existing IPE (International political economy) scholarship has largely focused on explaining patterns of incrementalism of EU level regulatory responses. Specifically, IPE scholars have attributed the incremental nature of regulatory reforms at EU level to the influence of financial-sector groups and their lobbying efforts aimed at preventing regulation (Buckley and Howarth,2010). The literature thereby echoed the popular capture narrative. This narrative has also been fed by media accounts of 'extremely vigorous' lobbying pressure from financial service-sector lobbyists during reform debates in Brussels (Hoedeman, 2009).

There is no doubt that consumer advocacy groups were largely outnumbered by industry sector lobbyists during reform debates. According to a recent study conducted by a Brusselsbased NGO entitled the 'The Firepower of the Financial Lobby', financial industry groups had seven times more encounters with EU institutions than NGOs, trade unions and consumer organizations taken together (Corporate Europe Observatory, 2014a). The financial industry clearly also had much more material resources at its disposal than civil society

\footnotetext{
* This essay was prepared at the Max Planck Sciences Po Center (MaxPo) and at the Centre d'études européennes at Sciences Po Paris and finalized at the Foundation of European Progressive Studies (FEPS) in Brussels. I would like to express my gratitude to all interview partners who gave their time to support this research. All responsibility is of course my own.
} 
groups. In 18 months between its foundation and December 2012, Finance Watch, a newly found Brussels-based NGO lobbying on financial reform spent $€ 330,000$ on communications, meetings and research (Finance Watch,2013). In 2012, the Deutsche Bank alone spent about $€ 1,990,000$ on lobbying for financial reforms at EU level. ${ }^{1}$

The goal of this analysis is to subject claims of regulatory capture in EU financial regulatory decision-making to more vigorous empirical scrutiny. By covering EU institutions, the present analysis takes on the empirical basis for regulatory capture arguments above the level of national policy-making. To date only a few studies have engaged with regulatory capture theories on international levels of governance (see for example, Chalmers,2015; Young,2012).

The empirical account draws on more than 70 elite interviews with industry representatives, civil society groups and policy-makers in Brussels between July 2011 and May 2013, as well as publicly available secondary sources such as newspaper articles and academic and professional publications about financial reforms. First, the article gives an overview of common theoretical perspectives. In section II, I demonstrate regulatory change that occurred with respect to consumer finance protection at EU level, assessing the extent to which diffuse interest groups saw their preferences met in the reform outcome. ${ }^{2}$ I show that private sector groups were not successful in preventing regulatory change despite their lobbying efforts. Going into greater detail about the role of newly mobilized non-financial groups, the present research will focus on a simple question: how can interest groups, usually considered as weak and peripheral in the context of finance, such as consumer associations, successfully have their preferences met in financial reforms despite the opposition of the financial industry that seeks to preserve the status quo? In section III, I describe the general post-crisis environment in which interest groups' lobbying took place and conduct detailed processanalyses of three regulatory policies enacted at EU level in response to the crisis, examining advocacy efforts of organized diffuse interest groups over the content of the proposed reform policies. In section IV, I will summarize the findings of the case studies before I briefly conclude.

In the case studies on the Mortgage Credit Directive (MCD) and stricter regulations of retail investment products (PRIPs/KID), I demonstrate that, despite a socio-institutional environment thought to be conducive to private sector influence, the influence of industry groups was more circumscribed and newly mobilized groups managed to translate some of their key advocacy goals into policy. In the third case study on the reform of supervisory structures, I demonstrate that efforts by advocacy groups to strengthen the consumer mandate largely failed. By asking why and how diffuse interests came to be represented in some policies, but not in others, we can start to single out the underlying mechanisms of diffuse interest representation in financial regulation. The starting point of the analysis is the preliminary policy response to the financial crisis in 2008, while the end point is roughly the end of the reform negotiations and the signing into law of reforms in 2014. Subsequent research will have to unpack the full implementation process of the financial reforms enacted in response to the crisis.

\footnotetext{
${ }^{1}$ See European Transparency Register, available online at: ec.europa.eu/transparencyregister/public/consulta-tion/ displaylobbyist.do id $=271912611231-56$.

${ }^{2}$ Evidence of influence or lobbying success of an interest group would be if 'a specific proposal articulated as part of a lobbying effort can be shown to have made its way into actual regulatory policy' (Young, 2012, p. 671). If, for instance, an item survives the policy agenda in spite of industry lobbying opposed to it, this evidence would be an empirical indicator for failed industry capture.
} 


\section{Theoretical Approaches}

In this section I will briefly review the most common theoretical perspectives on EU financial reform politics. A more 'pluralistic' view of financial reform making that takes into account the role of non-financial actors in shaping regulatory reform helps to understand reform cases where well-funded industry groups did not get what they wanted.

\section{Capture Theories}

Regulatory capture, a process whereby narrow industry interests are favoured at the expense of the more diffuse public interest, has arguably become the most popular theoretical concept to analyze post-crisis financial reform-making (Pagliari,2012, p. 6). ${ }^{3}$ This interpretation was echoed by many observers, who argued that national and international reform efforts after the crisis were considerably watered down or scaled back by private-sector lobbies (Helleiner etal., 2010; Moschella and Tsingou,2013). Political scientists studying post-crisis reforms in the EU, recorded incremental change with much activity but relatively little change (Moschella, 2014; Moschella and Tsingou, 2013). However, due to the assumption of regulatory capture, scholars have neglected to systematically examine reform cases where industry groups did not succeed. This bias is particularly true for scholarship unfolding in response to the financial crisis. Buckley and Howarth (2010, p. 137), for instance, attribute the incremental nature of reforms largely to successful lobbying of domestic financial industries aimed at preventing regulation. Tsingou (2010)testifies to the persistence of the influence of a transnational policy network of financial experts. Emphasizing 'close financial, personal and ideological ties' between policy-makers and the banking industry, Johnson and Kwak (2011, p. 12) argue that Wall Street returned to 'business as usual' after the crisis, with its political influence in Washington as powerful as ever. Admati and Hellwig (2013, p. 3), two renowned economists, argue that 'despite the enormous damage of the financial crisis of 2007-09, the effort to reform the financial system has been stymied'. While capture theories give us clues why reform efforts were rather incremental despite the major shock of the crisis, they are ill-equipped to explain cases where resourceful private sector groups were not able to translate their preferences into policy.

\section{Salience in EU Politics}

Highlighting the role of public salience, scholars increasingly emphasize that electoral contingencies and public opinion are causal factors that influenced post-crisis financial reform-makers (see, for example,Pagliari,2013). These studiesemphasize populist pressures on policy-makers together with an increased awareness of the distributional consequences of regulatory failures due to the crisis as driving factors for more stringent regulation of the financial sector. A small but growing number of studies testify that the crisis was a catalyst in changing interest groups dynamics in regard to financial regulation. Woll (2013) argues that regulatory reform had become susceptible to public outrage which forced financial industry lobbyists, in this case the hedge fund industry, to adapt

\footnotetext{
${ }^{3}$ Regulatory capture is here understood to be occurring "when bureaucrats, regulators and politicians cease to serve some notion of a wider collective public interest and begin to systematically favour specific vested interests, usually the very interests they were supposed to regulate and restrain for the wider public interest' (Baker, 2010, p. 648).
} 
their strategies to governments' preferences in order to be successful. Recent research has also shown that altered social relations within the financial policy network considerably weakened the industry's capacity to veto or block reform proposals. Young (2013) finds that increased issue salience was accompanied by a qualitative shift in policy-making with decision-makers becoming more reluctant to exchange information with industry groups and overall communication levels dropping significantly. Adjusting to these shifts the financial industry changed its advocacy strategy putting more emphasis on self-regulatory moves and delaying implementation instead of vetoing policy proposals (Young,2014). Steinlin and Trampusch (2012, p. 256) find that under political pressure banks were afraid of reputational repercussions and therefore refrained from using their veto possibilities to block change. Accounts that base their explanations of post-crisis regulatory reforms on salience as sole explanatory factor, do however neglect the agency of newly mobilized pro-reform forces. Most of the accounts above emphasize changed dynamics within the financial community with little attention paid to societal counter-mobilization from the bottom-up. Also, while salience arguments hinge on empirical evidence of increased public attention, EU-level consumer protection reforms did not attract much interest among a wider public.

\section{A Pluralist Perspective}

Recent insights from political economy suggest that the mobilization of outsider groups as a 'countervailing force' had significant effects on the regulatory design of post-crisis financial reforms (Clapp and Helleiner,2012; Kastner, 2014;Orban, 2016; Pagliari and Young,2014; Woolley and Ziegler,2011). Given the public outcry and emerging popular pressures in response to the financial crisis, recent efforts on the part of scholars to explain regulatory change pay surprisingly little attention to newly mobilizing societal groups as change agents. We therefore need a precise account of how diffuse interest groups were able to confront the powerful financial lobby to have their preferences met in regulatory reforms in a more systematic manner.Following existing studies, I will show that the ability of concentrated industry interests to affect either the policy agenda or the specific content of regulatory rules has been weakened in the context of the financial crisis, giving political leverage to groups traditionally considered as 'outsider groups' to finance. The causal mechanism is set in the post-crisis context which enhanced the capacity of actor groups usually classified as weak to take advantage of the (temporary) disempowerment of concentrated interests. I argue that small advocacy organizations have contributed to policy-makers' quest for more substantial reforms, by deploying expertise during legislative debates and exploiting splits among industry groups. That meaningful legislation is only enacted when a consumer interest coincides with a powerful producer interest - so-called 'Baptist-bootlegger' coalitions - is a common assumption about consumer protection politics.Although material resources matter, these kinds of mixed alliances even out material advantages one group might have vis-à-vis another group and therefore compensate for the weaker stance of public interest groups vis-à-vis business(Baumgartner et al.,2009). Specifically, I examine coalition-building efforts among countervailing interest groups as well as between these and policy-makers and the influence of these relationships on policy reforms. In a recent study, Baumgartner and Mahoney (2015)could show that policy-makers do not necessarily respond to the 
Table 1: Overview of the EU's Legislative Initiatives (Consumer Finance Protection)

\begin{tabular}{lll}
\hline Regulatory Policy & Reform measures in line with consumer groups' demands \\
\hline 1 & $\begin{array}{l}\text { New supervisory structure } \\
\text { Directives on ESRB and ESFS } \\
\text { (September 2010), following } \\
\text { the de Larosière report }\end{array}$ & $\begin{array}{l}\text { Transformation of level-3 Lamfalussy committees into } \\
\text { European Authorities in charge of micro-prudential } \\
\text { oversight and limited consumer protection mandate } \\
\text { (for example, right to ban harmful products). }\end{array}$ \\
$\begin{array}{ll}\text { Retail Financial Services } \\
\text { Mortgage Credit Directive }\end{array}$ & $\begin{array}{l}\text { Introduces for the first time EU-wide rules in the area } \\
\text { of mortgage loans, harmonizing and improving consumer } \\
\text { 2014/17/EU (February 2014) }\end{array}$ \\
$\begin{array}{ll}\text { Regulation for Packaged Retail regulations across Europe. } \\
\text { Investment Products (PRIPs) } \\
\text { (December 2014) }\end{array}$ & $\begin{array}{l}\text { Improves investor protection by introducing a standardized } \\
\text { key information document (KID) for non-vanilla products } \\
\text { which are risky, difficult to compare and complex to }\end{array}$ \\
& $\begin{array}{l}\text { understand to increase transparency and comparability } \\
\text { of products. }\end{array}$ \\
&
\end{tabular}

Source: Assembled by the author.

resources of individual lobbying groups, but take into consideration the overall structure of conflict and the likelihood of success of a policy solution. Policy-makers are not only passively being lobbied but may become active policy advocates ('legislative allies') themselves who join the efforts of groups with the same policy goals. The authors conceptualize 'lobbying groups and government officials as parts of collective efforts to move policy in one direction or another' in so-called insider-outsider coalitions (Baumgartner and Mahoney, 2015, p. 203). From this perspective the road to success is gaining government allies with shared policy goals, and not, as many interest group scholars have depicted it, outsider groups trying to lobby largely inactive government officials.

\section{Regulatory Change and Group Influence}

Table 1 summarizes the regulatory reforms chosen for analysis and lists their content with respect to consumer relevance.

The Mortgage Credit Directive ${ }^{4}$ adopted by the Commission in February2014, introduced for the first time EU-wide rules in the area of mortgage loans. ${ }^{5}$ It complemented the Consumer Credit Directiveof 2008, aimed at harmonizing consumer protection regulations and promoting market integration for consumer credit, by applying similar measures to mortgage loans. Prior to the crisis, no EU-wide legislation for home loans existed, except for a voluntary code of conduct, a self-regulation regime on information requirements, signed by the mortgage-lending industry and consumer groups in 2001. In the final Directive, pro-reform advocates saw important parts of their demands translated into policy. A general right for consumers to repay loans early, made it into the final Directive. To ensure that borrowers can meet their credit obligations, the

\footnotetext{
${ }^{4}$ Mortgage Credit Directive 2014/17/EU (former EU Directive on responsible lending and borrowing, also referred to as Directive on credit agreements relating to residential property, short CAARP).

${ }^{5}$ Member States had to transpose its provisions into their national law by March2016.
} 
legislation also heightens creditworthiness assessment standards. The reform also includes a general ban on tying practices where other financial products are packaged together with a credit agreement affecting consumers negatively, a provision not included in the initial Commission proposal, ${ }^{6}$ and pushed for by consumer advocates (Interview with a consumer advocate, Brussels, 21 May 2013). The Directive also introduces a minimum standard for advice and curbs misleading advertising of mortgage credit and creates an information requirement, in the form of a standardized information sheet (ESIS) that can be compared across-borders and facilitates shopping around. Although the new regulation does not ban loans in foreign currencies, as consumer groups had demanded, it introduces additional consumer safeguards in order to protect consumers against exchange rate risk, reflecting the proposition of The European Consumer Organization (BEUC). Accordingly, the Directive was received positively by consumer groups who considered consumer protection strengthened (BEUC,2013a). In contrast, industry groups interviewed for this research project reported that their lobbying efforts to prevent the Commission from focusing more on consumer protection than on market integration had failed (Interview with a financial industry lobbyist, Brussels, 13 May 2013).

A second legislative initiative under analysis here is a proposal for a Regulation for Packaged Retail Investment Products (PRIPs) introducing a new key information document (KID) for investors. The Commission introduced the proposal in July 2012, in an effort to further tighten consumer protection and rebuild investor confidence after the financial crisis. PRIPs are, simply put, investment products sold to retail customers. Since the financial crisis had shown that investment products were sold to costumers that were 'not right for them', the aim of the legislation was to make risks of retail investment products easier to understand and to increase comparability of different products (European Commission,2012). As of autumn 2016, the regulation requires that investment fund managers, insurers and banks provide consumers with a consumerfriendly information document about the investment product they intend to buy. The 'KID' uses clear and plain language to allow retail customers to compare products before they make an investment decision. While industry groups complained about more paper work, Finance Watch, a leading civil society advocacy group, praised the legislation as 'a win for consumer protection in Europe that could help to reduce misselling'(Finance Watch,2014).

In an effort to address failures in supervision revealed by the crisis, one of the first legislative steps of decision-makers was to reform EU level supervisory structures, the third case study under consideration here. The Commission put forward a legislative proposal in September 2009, introducing major institutional innovations including three new pan- European Supervisory Authorities (ESAs) in charge of micro-prudential supervision. Within the new framework, consumer protection falls within the jurisdiction of the three ESAs that work in tandem with the existing national supervisory authorities. Advocates' lobbying efforts to secure a strong consumer mandate for the new authorities largely failed. Consumer groups and NGOs denounced the new ESAs for placing too little

\footnotetext{
${ }^{6}$ Proposal for a Directive of the European Parliament and of the Council on credit agreements relating to residential property, 2011/0062 (COD), 31 March 2011. Available online at: http://register.consilium.europa.eu/doc/srv?l=EN\&f=ST\% $208680 \% 202011 \% 20$ INIT.
} 
importance on consumer protection in their mandate as well as for the unbalanced composition of their stakeholder groups (Interview with a representative of an NGO, Brussels, 9 June 2011). In September 2011, BEUC submitted a complaint to the EU Ombudsman about the under-representation of consumer advocates within the stakeholder groups (BEUC,2011).

From the perspective of capture theories, where regulatory change depends upon the means and the power of the financial industry lobby to (re-)shape regulatory reform, we would expect the outcome to reflect domestic financial sector preferences. Although overall consumer protection reforms were rather incremental and compromised solutions, they nevertheless reflect certain policy alterations prompted by pro-reform advocates. These results suggest that factors other than material resourcefulness may have actually been decisive in these conflicts. A theoretical position that claims massive and ongoing impact of business power appears difficult to reconcile with this empirical evidence. Taken together, then, there is good evidence against the prevailing argument in the IPE literature that financial industry groups massively influenced or 'captured' regulatory reform. Why did diffuse consumer interests come to be reflected in some legislative outcomes but not in others?

\section{Contextual Conditions Underlying EU Financial Reforms ${ }^{7}$}

The financial crisis had considerably reshaped the context in which regulatory reform was taking place. Increased salience in the post-crisis reform period was accompanied by a deep legitimacy crisis of the financial services industry. Whereas relations among policy-makers and industry groups were previously described as 'cozy' or 'symbiotic'(Tsingou,2008), the financial crisis changed this interaction. Relations after the crisis came under stress, marked by policy-makers' reservation and even mistrust $v i s$-à-vis industry groups. In the perception of many policy-makers, financial industry groups were the culprits for the crisis. This perspective was clearly reflected in the European Parliament's resolution issued in July 2011 that 'banks [...] also bear their share of responsibility for the irresponsible lending practices [...]. ${ }^{8}$ According to one industry lobbyist: 'We are perceived by policy makers as being responsible for the current crisis which puts us in a difficult position' (Interview with a financial industry lobbyist, Brussels, 22 May 2013). The crisis had drastically changed the lobbying environment in which financial industry groups had to operate. Anecdotal evidence from interviews with industry representatives in Brussels suggests that divisions among decision-makers and financial sector groups occurred with Commission officials and MEPs giving industry lobbyists 'a very tough time' (Interview with a financial industry lobbyist, London, 17 June 2013). Communication levels seemed to have dropped significantly with industry representatives reporting that they found it often difficult to get appointments with MEPs (Interview with consumer advocate, Brussels, 1 June 2013).Industry groups felt that there was considerable stigma notably among MEPs. One industry representative described the

\footnotetext{
${ }^{7}$ This section is based on interviews with financial industry lobbyists, conducted in Brussels and London in May and June 2013.

${ }^{8}$ European Parliament Resolution of 6 July 2011 on the Financial, Economic and Social Crisis (2010/2242(INI)). Available online at: www.europarl.europa.eu/sides/getDoc.do?pubRef=-//EP//NONSGML+TA + P7-TA-2011-0331 + 0 + DOC $+\mathrm{PDF}+\mathrm{V} 0 / / \mathrm{EN}$
} 
context of political debate in the EP as 'bashing the banks'.In general, industry lobbyists struggled to get access to the policy process, with changes to pre-crisis levels clearly evident, as this interviewee put it, 'it is not as nice as it was 15 years ago. It has become more difficultthan it was'. Divisions among decision-makers and industry groups became increasingly visible when Commissioner Barnier asked his staff in December 2013 not to accept any more meetings with financial industry lobbyists for a certain period of time. The instructions were clearly laid out in an email from the Directorate General for Internal Market and Services (DG Markt), saying that '[i]n view of our workload and the sensitivity of our current dossier, until instructed otherwise Market DG employees should not meet with bankers, their representatives or their associations'(Corporate Europe Observatory, 2014b). Policy-makers generally also started to call the industry's expertise into question. A Commission official confirmed that the interaction with financial industry groups had become 'an adversarial relationship' after the crisis. He reported that industry groups had become 'less a source of information but more of an adversary because [the Commission] want[s] to change the way they do business'. With their reputation highly damaged in light of the financial meltdown, industry groups were put on the defensive and started changing their lobbying strategies. Some private sector participants interviewed for this project noted that they refrained from openly opposing or even vetoing legislative proposals. These qualitative shifts in policy-making, albeit anecdotal, indicate that financial industry groups' access to the policy-making process was curtailed after the financial crisis, thereby clearly reducing the sectors' overall political influence. These changes are important, since they suggest that the financial lobby's political leverage had temporarily decreased. The next section will show that the retreat of the industry opened-up new opportunities for alternative societal actors.In what follows I describe some of the advocacy activities of diffuse interest groups surrounding each of the policies under analysis, and document which of these were successful and which were not. The focus here is on EU-based diffuse interest groups, the way they mobilized and built pro-reform coalitions with governmental allies to induce desired changes in the content of consumer finance protection reforms.

\section{Case Study 1: European Mortgage Credit Directive (MCD)}

The new MCD Directive consolidates legislation on EU level, essentially harmonizing European mortgage regulations by setting the minimum regulatory requirements in a consistent way across Member States. In response to a Commission's consultation in 2009, industry groups strictly opposed new EU level mortgage regulations. Major European level financial industry associations including the European Banking Industry Committee (EBIC), the European Mortgage Federation (EMF), and the European Association of Cooperative Banks (EACB), as well as national associations such as the Association of German Public Sector Banks (VÖB) started lobbying the Commission on the Directive proposal before its issuance in March 2011 (Interview with financial industry lobbyist, Brussels, 13 May 2013). In an effort to avoid legislative action, banks and mortgage lenders tried to lay out a different narrative arguing that the mortgage crisis was specific to the US securitization system, a system of funding of mortgages not widespread in Europe (Interviews with financial industry lobbyists, Brussels 13, May and 24 June). These lobbying efforts failed to prevent the Commission from introducing 
new binding rules for mortgage regulations. From the industry perspective the Commission' proposal marked a 'conspicuous' shift in regulatory focus 'from internal market integration towards more consumer protection issues'(Ahlswede,2011). Other industry lobbyists confirmed that their lobbying efforts to prevent the Commission from focusing more on consumer protection than on market integration had failed and that they 'certainly didn't agree with this switch'.

Throughout the reform process, actor plurality was considerably increased compared to pre-crisis levels with consumer advocates actively supporting regulatory change. About 30 per cent of groups that participated in the Commission's public pre-legislative consultation in June 2009 came from consumer advocacy groups, consumer and user organizations as well as trade unions, about 20 per cent more groups than participated in financial sector consultations during pre-crisis times. ${ }^{9}$ National consumer associations served as an important information transmitter about abusive practices in relation to mortgage loans. The Commission noted that consumer advocates "provided examples of practices of unfair advertising and marketing'(European Commission,2009).

DG Markt under Commissioner Barnier became an important ally for diffuse interest groups in pushing for reform despite objections of banks and mortgage lenders. The Commission had discussed reforms related to mortgage integration well before the financial crisis, but DG Markt had refrained from introducing EU level legislation.Under the leadership of Commissioner Barnier, the Commission came up with a new proposal for a Directive on credit agreements relating to residential property(CARRP) addressing 'irresponsible lending and borrowing practices'(European Commission,2011). The objectives of the Commission proposal, officially tabled in March 2011, were twofold. It tried fostering consumer confidence by enhancing consumer protection and driving cross-border lending by introducing a maximum harmonization approach (Tait,2011). Consumer groups, who generally favoured a broad scope of the Directive and a minimum harmonization approach in order to preserve 'already existing national consumer-friendly legislation'(BEUC,2011) saw their demands largely reflected in the Commission proposal.

In April 2011 legislative debate moved to the EP, where in particular MEPs of the S\&D and the Green Party became important channels through which consumer groups could articulate their policy preferences. In July 2011 the ECON Rapporteur, Spanish MEP Sánchez Presedo (S\&D) issued his draft report which mainly differed in scope to the Commission proposal. The report introduced several new articles to the Commission's initial proposal.Despite disagreements about details of the legislation, working relations among consumer advocates and rapporteur were close throughout the legislative process. The socialist rapporteur relied heavily on expertise provided by consumer advocates who he regarded as close 'allies' during reform debates (Interview, Brussels, 21 May 2013).

The ECON draft report was met with substantial criticism. Consumer and industry groups agreed that the rapporteur addressed specific deficits of the Spanish mortgage market that were hardly transferable to the European level. Eventually, under pressure from the ECON shadow rapporteurs as well as industry groups, the rapporteur reduced the scope of the proposal. Subsequently, a 'compromise mid-way' between the

\footnotetext{
${ }^{9}$ In a study on the sectoral origin of groups mobilizing on financial sector consultations, Pagliari and Young (2012) found that prior to the crisis less than 10 per cent of respondents represented non-financial groups.
} 
'big-bang-approach' of the rapporteur and the 'step-by-step approach' of the Commission was forged (Interview with Commission official, Brussels, 22 May 2013). In the compromise position of the EP, provisions introduced by the ECON report had either been deleted (such as the provision on portability of loans) or watered-down by industry lobbying. Provisions that creditors should identify products that are not unsuitable for the consumer and that EBA should develop guidelines for creditworthiness assessments that were supported by the S\&D and the Green Party had been deleted, in line with industry preferences and after pressure from the EPP, ALDE and ECR groups (Giegold,2012).

While consumer advocates found support from the Commission and rapporteurs in the EP, industry groups successfully lobbied their Member States in the Council as well as the national MEPs to water down reform proposals. When the legislative debate moved to trialogue stage in June 2012, Member States pushed for even greater watering down of the new articles added by the EP. The final text of the Directive had largely been reduced to its narrow scope with the rapporteur's added articles deleted or watered down (Interview with financial industry lobbyist, Brussels, 13 May 2013). Although industry groups managed to water-down legislation, the reform outcomewas a settlement among the various stakeholder groups involved. Consumers are being granted a general right to early repayment but lenders are entitled to a compensation fee. The final Directive introduced Europe-wide standards for assessing the creditworthiness of mortgage applicants, but in line with industry demands, the text of the initial proposal suggesting an obligation for lenders to deny credit was deleted (European Commission, 2013). To industry groups, the outcome was a compromise they 'could live with' (Interview with financial industry representative, 14 May 2013).

\section{Case Study 2: Retail Investment Products (PRIPS/KID)}

The European Institutions varied significantly in their initial negotiating positions on the KID regulation (Costermans,2014). The scope of the regulation was one of the most controversially discussed items, with the EP promoting a wider scope and the Council trying to reduce the scope, largely echoing the Commission proposal (Interview with NGO representative, Brussels, 15 May 2013).In April 2014, EP and Council agreed the final text which came into force in December 2014. The agreement in trialogue largely followed the EP's consumer-friendly position, despite opposition of segments of the financial services industry. While pension funds had successfully lobbied for an exemption, certain insurance products do fall within the scope of the KID. Reflecting these changes to the initial Commission proposal, the final regulation was named PRIIPs, including not only 'packaged retail,' but also 'insurance-based investment products.'

Opposition to the Commission proposal and subsequent EP amendments came from the savings and co-operative banks that were not eager to implement another key information document and complained about an obligation to provide more paperwork when selling services. Insurance companies and pension funds lobbied Member States in the Council to be excluded from the scope of the new PRIPS regulation (Johnson,2013). These industry groups were clearly not in favour of the EP's ambitious amendments and extension of scope for the Directive, describing the parliamentary debate as 'highly political,' 'dangerous' and marked by 'miscomprehension of what the Commission idea was'(Interview with industry representative, Brussels, 22 May 2013). 
The reform debate surrounding the PRIPS regulation illustrates how the policy influence of diffuse interest groups can be boosted by powerful industry interests when the two find themselves on the same lobbying side. Industry groups werenot united in their opposition to new regulations. The insurance sector was split, with British and Dutch insurance companies supporting the creation of a level-playing field through new legislation and French and German companies strongly resisting the inclusion of insurance products. 'Baptist-bootlegger' coalitions emerged among consumer groups and the European fund industry against parts of the insurance sector. The larger scope of the Directive was in line with the European fund industry which lobbied for more regulation of the growing sector of retail structured products, in order to address a lack of level playing field across retail investment products (Interview with Commission official, Brussels, 21 May 2013). The European fund industry was also supportive of the introduction of a KID covering a wide range of investment products, including pension funds and was largely aligned with consumer representatives in their support for the Commission's proposal to enhance investor protection (Interview with industry representative, Brussels, 22 May 2013). A broad range of groups ranging from European Investors and Users of Financial Services including EuroFinUse (European Federation of Financial Services Users) to Financial Advisers, Asset Managers and Life Insurance Companieswas in favour of the Commission's proposal. In a joint press release of end users and asset management industry in July 2012, groups expressed their full support(CFA Institute,2012).

Pro-reform groups, including BEUC, Finance Watch, EuroFinUse and the Financial Services Users Group (FSUG) at the European Commission generally supported the Commission's proposal aimed at enhancing investor protection by making the provision of an information document about investment products mandatory. They advocated for widening the scope, making the KID mandatory for all saving and investment products and for life insurance and pensions to be within the scope of the proposal so that consumers would be able to compare products across asset classes as well as within the same asset class. In-depth discussions had already taken place among Finance Watch and Commission officials before the Commission published its legislative proposal in July 2012 (Interview with civil society representative, Brussels, 15 May 2013).Reform advocates stepped up their lobbying efforts targeted at MEPs before the vote in plenary in November 2013. In May and June 2013, Finance Watch circulated mock-up Key Information Documents showing how their reform suggestions could work in practice (Finance Watch,2013). In November, BEUC, EuroFinUse and Finance Watch joined forces to write a letter to members of the ECON Committee advocating for a wide scope of the new regulation. The letter was followed with emails of the advocacy groups to all MEPs, urging them to defend complexity labels. BEUC issued a press release, promoting a wide scope of the regulation(BEUC,2013b).

Insider-outsider coalitions emerged with consumer advocates and MEPs pushing for the same policy solutions. In the fall of 2012, meetings among Finance Watch staff and the shadow rapporteurs for the PRIPs dossier took place, where advocates pushed for a warning label and a wider scope. Rapporteur Bères (S\&D) became an important ally for advocacy groups promoting the consumer cause in the ECON Committee. As a result of the team-like preparation of the legislation with MEPs and advocacy groups collaborating, all of the recommendations that had been brought to the table by Finance Watch were 
either taken up by the rapporteur's draft report published in December 2012 or were presented as amendments by MEPs. Following advocates' proposals, the rapporteur's draft report included a wide scope of the regulation, including stocks, bonds and bank deposits as well as additional product rules (Interview with civil society representative, Brussels, 15 May 2013).Echoing the suggestion by Finance Watch, the rapporteur also included a provision on information about environmental, social and governance (ESG) criteria in the KID. MEP Sharon Bowles (ALDE, UK), then chairwoman of the ECON Committee, included a complexity label (or warning label) as suggested by Finance Watch (Flood,2013b). Although the EP had been deeply divided over the PRIPs regulation, and despite opposition of the EPP to extending the scope (Flood,2013a), MEPs finally adopted the new regulation introducing a range of amendments to the initial Commission draft.Advocates also saw a considerable part of theirpositions reflected in the final legislation, including a wider scope (including certain insurance products), a warning label for certain investment products, enhanced disclosure of financial advisor fees and a provision for product issuers to substantiate claims about environmental and social objectives of an investment product. ${ }^{10}$

\section{Case Study 3: New European Supervisory Authorities (ESAs)}

The new supervisory framework for financial regulation in the EU came into force in January 2011. The new supervisory authorities - European Banking Authority (EBA), the European Insurance and Occupational Pensions Authority (EIOPA) and the European Securities and Markets Authority (ESMA) - transformed and upgraded the existing supervisory structure of three so-called Lamfalussy level 3 advisory committees into 'bodies with greater supervisory, rule-setting, and co-ordinating powers' (Eisinget al.,2013). The ESAs have a mandate to protect consumers against abusive practices, with consultative 'Stakeholder Groups' representing consumer associations in all three organizations. ${ }^{11}$ Overall, the consumer protection mandate of the ESAs remained limited. Staffing levels are low and the ESAs have no competence to impose binding rules on national regulators in the field of consumer protection (BEUC,2013c).

A European supervisory framework was opposed by parts of the financial industry, notably the German LBs, savings and co-operative banks, which reportedly influenced the German position. German LBs tried to preserve their competitive advantage under national supervision which provided a degree of protection from increased competition under a single European supervisory framework (Buckley and Howarth,2010, p. 128). Industry opposition to regulatory change was however not unanimous. Consumer demands in favour of a move towards strengthened EU supervision were echoed by the European fund industry who supported a harmonized European supervisory framework with strong authorities (EurActive, 2010) as well as large German commercial banks who expected lower compliance costs. During negotiations, neither the German nor the French government could maintain their opposition to EU level supervision and had to soften their position (Buckley and Howarth,2010, p. 128).

\footnotetext{
${ }^{10}$ Regulation (EU) No 1286/2014.

${ }^{11}$ Regulation (EU) No 1092/2010.
} 
Consumer groups, including Consumers International, FIN-USE, BEUC, the Federation of German Consumer Organizations, Which? and trade unions, got actively engaged in the reform debate. ${ }^{12}$ The mobilization of diffuse interests and their participation in the legislative process remained, however, limited with only 12 consumer groups and trade unions participating in the public consultation, representing only about 13 per cent of consultation submissions. Consumer groups generally argued in favour of one single European Authority in lieu of three different agencies to replace the Lamfalussy committees to ensure strong co-operation among national regulators (BEUC,2009). Consumer advocates preferred a single centralized European Financial Regulatory Authority to set prudential standards, act as co-ordinator-supervisor for larger EU-wide financial institutions that represent systemic risk to the financial system of the EU, and set standards for valuing financial assets (FIN-USE,2009). Modeled after the US Dodd-Frank Bill, advocates also proposed to set up a pan-EU Consumer Protection Agency along-side the new supervisory authorities. In response to the Commission consultation, various consumer groups argued in favour of the creation of a consumer regulator (a 'European Financial Users Authority') modeled after the American Consumer Agency(see, for example, The Federation of German Consumer Organizations, Vzbw,2009). Re-Define, a Brussels-based think tank suggested a consumer regulator 'with additional powers to enforce high levels of disclosure, good faith transactions and strong and robust recourse against wrongdoers' (Kapoor,2010). However, during the negotiations, consumer groups had to soften their position to advocate for a strong consumer mandate of the ESAs instead of an independent consumer regulator (BEUC,2010).

The EP became an important 'agent of change', in support of strong supervisory authorities with adequate financial and human resources (Quaglia,2013, p. 59). While Member States had considerably weakened the legislation, MEPs tried to restore the initial Commission proposal and to further strengthen the statutory powers of the new authorities (Brunsden,2010). Member States in the Council, in particular the UK, France and Germany, were rather reluctant about transferring supervisory powers to supranational authorities (Buckley and Howarth,2010, p. 127). The EP, on the contrary, envisaged the new authorities as 'watchdogs with a bite', with the ability to write regulatory standards, to temporarily ban harmful products, to make legally binding decisions for national financial institutions and to require a review from the Commission every three years that could potentially strengthen the supervisors even more by integrating them into one supervisory body (European Parliament 2015). In plenary debate in Strasbourg in September 2010, MEPs repeatedly warned against Council efforts to water down legislation and highlighted their support for a strong consumer protection mandate for the new institutions. In particular, Green MEP Sven Giegold (German) became an important ally for consumer groups pushing consumer-friendly legislation through the ECON Committee as rapporteur for the legislation (Interview with NGO representative, London 6 July 2011).Giegoldadded amendments reinforcing consumer protection, notably by granting the ESAs the right to prohibit certain financial products. In line with demands of consumer groups, the EP also insisted on representatives from civil society in

\footnotetext{
${ }^{12}$ See public submissions to the Commission consultation on European Financial Supervision in July 2009, available online at: ec.europa.eu/internal_market/consultations/2009/fin_supervision_en.htm.
} 
consultative stakeholder groups. Despite initial reluctance of Member States to transfer regulatory powers to the supranational level, the EP successfully pushed for strengthened supervisory authorities in the final legislation (Quaglia, 2012, p. 187). In line with preferences of the Member States, national regulators, however, mainly retained their regulatory functions with regards to day-to-day supervision. The final regulatory outcome fell short of establishing authorities with a strong consumer mandate as envisioned by pro-reform advocates.

\section{Summarizing the Case Studies}

This section summarizes the findings from the reform initiatives studied above. Analyzing the introduction of new binding mortgage rules in the Mortgage Credit Directive, the analysis demonstrates that private sector lobbying efforts aimed at preventing legislative action failed. The final reform legislation was a compromise with both lobbying sides consumer associations and industry groups - achieving some of their goals. In the second study on the stricter regulations of retail investment products, I showed that consumer groups were able to successfully push amendments through the EP and subsequent trialogue negotiations, including warning labels for certain investment products and enhanced disclosure of fees. In contrast, consumer groups saw their demands ignored concerning a consumer regulator modeled after the American consumer agency alongside new authorities or to integrate the authorities under a strong centralized EU-level supervisory body. The findings demonstrate the complexity of diffuse interest group representation in financial regulation. Advocacy success cannot be understood solely with reference to favourable political opportunity structures or groups mobilization efforts. To produce a favourable outcome to consumer interests, several factors had to play together. The following elements can be considered necessary to produce a regulatory outcome reflecting diffuse interest groups advocacy goals: (1) post-crisis conditions weakened the financial industry and increased political receptivity to pro-reform demands, (2) diffuse interest groups mobilized in coalitions, deployed expertise and exploited industry splits, and (3) found allies in Commissioner Barnier and rapporteurs in the EP that actively pushed for policy change throughout legislative debates. The comparison of the cases also reveals that the European Commission and Parliament, rather than the Council, are instrumental in achieving consumer-friendly outcomes. MEPs support for consumer protection policies can be explained by their motivation to portray the EP as the institution representing citizens' interests and as an ally of the general public. In particular the S\&D and the Green party proved to be receptive to the preferences put forward by pro-reform groups, while MEPs of the EPP group were more industry-friendly.

\section{Conclusions}

This article presents empirical evidence that in the context of the financial crisis legislators were keen to punish the financial industry with new regulations. Although it is difficult to establish an independent causal role of NGO influence, the case studies support the conclusion that consumer advocates became insiders of the reform process. This is evidenced by various examples of measures initiated by NGOS, such as a ban 
on tying practices that was not included in the initial proposal of the Commission for a Mortgage Credit Directive or warning labels for certain investment products and enhanced disclosure of fees as in the case ofretail investment product regulation. The case studies on the MCD and the PRIPS regulation show that the Commission and the proreform forces within the European Parliament benefited from NGOs as 'legislative allies' to push reforms through the legislative process. This alliance proved to be beneficial to Commissioner Barnier (in the case of the mortgage credit reform)as well as to the rapporteurs in the EP in their efforts to push for reform in spite of industry opposition. Consumer groups served an important source of expertise for both Commission officials and MEPs. This finding is best exemplified by the team-like preparation of the PRIPS legislation with MEPs eventually taking up all of Finance Watch's policy recommendations. In particular the more consumer-friendly S\&D and the Green party were able to take advantage of the increased civil society mobilization. Findings of the case studies also suggest that diffuse interests' success in the Parliament mainly hinges on the rapporteurs because they have to steer the legislative proposals through the ECON Committee and the plenary vote. Examples are the part played by Sven Giegold (Greens) in securing amendments to strengthen the new European Supervisory Authorities by granting them the right to prohibit certain financial products and the work of Pervenche Bères $(S \& D)$ in pushing through the amendments to the KID Regulation, as suggested by pro-reform advocates. With respect to the reform of mortgage credit regulations, the rapporteur Antolín Sánchez Presedo (S\&D) prevented a watering-down of the Commission proposal. Consumer protection measures were also strengthened when industry opposition split and strange bedfellow coalitions emerged among consumer advocates and the financial services industry, as in the case of the KID Regulation, when user representatives and European fund industry supported stricter EU regulations, against the opposition of other industry groups. However, when key Member States oppose a proposal, as in the case of the ESAs, NGO support of pro-reform forces within the Commission and the Parliament has little to no effect.

What are the broader theoretical lessons that we can draw from the case studies presented here? Findings are in line with Pagliari and Young's (2014) observation that enhanced actor plurality with more end users of financial services, NGOs and consumer organizations participating in the policy process reduces the dominance of the industry voice during legislative debates. It reduces the risk of outright industry capture and makes a more compromised legislative outcome, reflecting various stakeholder preferences, more likely. The creation of Finance Watch in 2011 is one example of a participatory mechanism for diffuse interest groups to systematically increase actor plurality in regulatory decision-making by directly sponsoring an NGO as a counterweight to industry. My case studies suggest that the new mechanisms worked well to include a consumer and user perspective in post-crisis reform debates. However, an important caveat is in order here: almost one decade after the financial crisis, the European Institutions' engagement with civil society has started to fade, as showcased by the Commission's announcement in 2016 to curb funding for the FSUG. There is one, albeit cynical, silver lining to this finding that civil society mobilization therefore only temporarily curtailed regulatory capture: the crisis-prone development of capitalism is likely to continue to generate conditions favourable to civil society influence. 
Correspondence:

Lisa Kastner

Max Po - Max Planck Sciences Po Center on Coping with Instability in Market Societies

27 rue Saint-Guillaume

75337 Paris Cedex 07

France

email: lisa.kastner@sciencespo.fr

\section{References}

Admati, A. and Hellwig, M. (2013) The Bankers' New Clothes: What's Wrong with Banking and What to Do about It (Princeton, NJ: Princeton University Press).

Ahlswede, S.(2011)'Consumer Protection in Financial Services'. Deutsche Bank Research. Available online at: www.dbresearch.de/PROD/DBR_INTERNET_EN-PROD/ PROD0000000000273424.pdf.

Baker, A. (2010) 'Restraining Regulatory Capture? Anglo-America, Crisis Politics and Trajectories of Change in Global Financial Governance'. International Affairs, Vol. 86, No. 3, pp. 647-63.

Baumgartner, F. and Mahoney, C. (2015) 'Partners in Advocacy: Lobbyists and Government Officials in Washington'. The Journal of Politics, Vol. 77, No. 1, pp. 202-15.

Baumgartner, F.R. et al. (2009) Lobbying and Policy Change: Who Wins, Who Loses, and Why (Chicago, IL: University of Chicago Press).

BEUC (2009) 'Financial Supervision in the EU Report of the High-Level Group \& 'Driving European Recovery' the Commission Communication - BEUC's Response', 10 April. Available online at:circabc.europa.eu.Last accessed: 15 December 2016.

BEUC (2010) 'Financial Supervision at EU and National Levels. Consumer Interests-BEUC Position', 4 March. Available online at: beuc.org/publications/2010-00147-01-e.pdf.Last accessed: 15 December 2016.

BEUC (2011)'EU Ombudsman to Probe Financial Supervision', 14 September. Available online at: beuc.eu/publications/2011-09744-01-e.pdf. Last accessed: 15 December 2016.

BEUC(2013a)‘No Home Run for Home Loans', 10 September. Available online at: beuc.org/publications/2013-00546-01-e.pdf.Last accessed: 15 December 2016.

BEUC (2013b) 'EU Moves to Lift Financial Investment Product Fog, PR 2013/025', 19 November. Available online at: beuc.org/publications/pr2013_025e_kid_plenary_vote.pdf. Last accessed: 15 December 2016.

EUC (2013c) 'Review of the European System of Financial Supervision-BEUC Response', 23 August. Available online at: beuc.org/publications/2013-00558-01-e.pdf.Last accessed: 15 December 2016.

Brunsden, J. (2010) 'Council at Odds with MEPs over Reforms', European Voice, 17 February. Available online at: europeanvoice.com/article/council-at-odds-with-meps-over-reforms/.

Buckley, J. and Howarth, D. (2010) 'Internal Market: Gesture Politics? Explaining the EU's Response to the Financial Crisis'. JCMS, Vol. 48, No. September, pp. 119-41.

CFA Institute (2012) 'PRIPs Regulation Must Put the Interests of Investors First, Say European Investors, Users of Financial Services, Financial Advisers, Asset Managers and Life Insurance Companies Operating Cross-Border', 3 July. Available online at: cfainstitute.org/about/press/ release/Pages/07032012_68993.aspx.

Chalmers, A. (2015) 'Financial Industry Mobilization and Securities Markets Regulation in Europe'. European Journal of Political Research, Vol. 54, No. 3, pp. 482-501.

Clapp, J. and Helleiner, E. (2012) 'Troubled Futures? The Global Food Crisis and the Politics of Agricultural Derivatives Regulation'. Review of International Political Economy, Vol. 19, No. 2, pp. 181-207. 
Corporate Europe Observatory (2014a) 'The Fire Power of the Financial Lobby', April. Available online at: corporateeurope.org/sites/default/files/attachments/financial_lobby_report.pdf. Last accessed: 15 December 2016.

Corporate Europe Observatory (2014b) 'Barnier's Ban on Meetings with Lobbyists', 13 January. Available online at: corporateeurope.org/blog/barnier-ban-meetings-lobbyists.

Costermans, D. (2014) Banking Transformation: The Case of Private Banking From Private Banking to Wealth Management: Survival of the Fittest. Newsletter Issue 21 (The Luxembourg Financial Connection, Luxembourg: EY).

Eising, R., Rasch, D. and Rozbicka, P. (2013) 'EU Financial Market Regulation and Stakeholder Consultations'. Paper presented at the Institute for European Studies, Université Libre de Bruxelles, 18-19 April.

EurActive (2010) 'EU Passes 'Historic' Agreement on Bank Supervision', 23 September. Available online at: euractiv.com/financial-services/eu-votes-historic-agreement-bank-supervision-news-498050.

European Commission (2009) 'Financial Services: Commission Launches Consultation on How to Ensure Responsible Lending and Borrowing in the EU', IP/09/922, 15 June. Available online at: europa.eu/rapid/press-release_IP-09-922_en.htm?locale=en. Last accessed 15 December 2016.

European Commission (2011) 'New Rules for More Efficient, Resilient and Transparent Financial Markets in Europe', IP/11/383, 20 October. Available online at: europa.eu/rapid/pressrelease_IP-11-1219_en.htm?locale=en. Last accessed 15 December 2016.

European Commission (2012) 'Commission Proposes Legislation to Improve Consumer Protection in Financial Services', IP/12/736, 3 July. Available online at: europa.eu/rapid/pressrelease_IP-12-736_en.htm?locale=en. Last accessed: 15 December 2016.

European Commission (2013) 'Statement by Commissioner Michel Barnier Following the Agreement in Trilogue on the Mortgages Directive', 22 April. Available online at: europa. eu/rapid/press-release_MEMO-13-365_en.htm. Last accessed: 15 December 2016.

European Parliament (2015) 'Parliament Gives Green Light to New Financial Supervision Architecture', 22 September. Available online at: europarl.europa.eu/news/en/news-room/content/20100921IPR83190. Last accessed: 15 December 2016.

Finance Watch (2013) 'Discussion Paper on Product Rules for Retail Investment Products', 19 April. Available online at: finance-watch.org/our-work/publications/627.

Finance Watch (2014) 'PRIPs Agreement Should Help to Reduce Mis-Selling of Financial Products to Consumers, Says Finance Watch', 1 April. Available online at: finance-watch. org/press/press-releases/857.

FIN-USE (2009) 'The Future of Financial Services Supervision', April. Available online at: ec.europa.eu/internal_market/fin-use_forum/docs/supervision_en.pdf.

Flood, C. (2013a) 'Deep Divide over EU Retail Investor Protection Vote', Financial Times, 22 September. Availabe online at: ft.com/intl/cms/s/0/8f90bf1e-2133-11e3-8aff-00144feab7de. html?siteedition=uk\#axzz3UZVEtNZn.

Flood, C. (2013b) 'Prips: EU Parliament 'Betrays' Retail Investors', Financial Times, 27 October. Available online at: ft.com/intl/cms/s/0/cf71e2a2-3b19-11e3-87fa-00144feab7de. html\#axzz3UZVEtNZn.

Giegold, S. (2012) 'Abstimmung zu Wohnimmobilienkrediten:Erfolge beim Ver-braucherschutz, Marktrisiken bleiben unangetatstet', 7 June. Available online at: sven-giegold.de/2012/ abstimmung_zu_wohnimmobilien/

Helleiner, E., Pagliari, S. and Zimmermann, H. (2010) Global Finance in Crisis: The Politics of International Regulatory Change (New York: Routledge).

Hoedeman, O. (2009) 'New Europe-The Financial Crisis', Corporate Europe Observatory, 11 October. Available online at: corporateeurope.org/coverage/new-europe-financial-crisis. 
Johnson, S. (2013) 'Consumer Body Fights Pension Lobby', Financial Times, 13 January. Available online at: ft.com/intl/cms/s/0/27738246-5c02-11e2-bef7-00144feab49a. html\#axzz3UZVEtNZn.

Johnson, S. and Kwak, J. (2011) 13 Bankers: The Wall Street Takeover and the next Financial Meltdown (New York: Vintage Books).

Kapoor, S. (2010) Better Consumer Protection and Tackling Systemic Risk-Two Sides of the Same Coin? (Brussels: Re-define).

Kastner, L. (2014) 'Much Ado about Nothing? Transnational Civil Society, Consumer Protection and Financial Regulatory Reform'. Review of International Political Economy, Vol. 21, No. 6, pp. 1313-45.

Moloney, N. (2012) 'The Legacy Effects of the Financial Crisis on Regulatory Design in the EU'. In Hill, J.G. and Moloney, N. (eds) The Regulatory Aftermath of the Global Financial Crisis (Cambridge: Cambridge University Press), 111-202.

Moschella, M. (2014) 'The Institutional Roots of Incremental Ideational Change: The IMF and Capital Controls after the Global Financial Crisis'. The British Journal of Politics \& International Relations, Vol. 17, No. 3, pp. 442-60.

Moschella, M. and Tsingou, E. (2013) Great Expectations, Slow Transformation: Incremental Change in Post-Crisis Regulation (Colchester: ECPR Press).

Orban, A. (2016) 'Mobilizing Moral Boundaries: the Politics of Derivatives Reform in the US'. New Political Economy, Vol. 21, No. 6, pp. 555-73.

Pagliari, S. (2012) 'How Can We Mitigate Capture in Financial Regulation?' In Pagliari, S. (ed.) Making Good Financial Regulation. Towards a Policy Repsonse to Regulatory Capture (Guildford: Surrey: Grosvenor House Publishing Ltd.), 1-50.

Pagliari, S. (2013) Public Salience and International Financial Regulation. Explaining the International Regulation of OTC Derivatives, Rating Agencies, and Hedge Funds, PhD thesis, Canada: University of Waterloo.

Pagliari, S. and Young, K.L. (2012) 'Who Mobilizes? An Analysis of Stakeholder Responses to Financial Regulatory Policy Consultations'. In Pagliari, S. (ed.) The Making of Good Financial Regulation (London: International Center for Financial Regulation), 48-56.

Pagliari, S. and Young, K.L. (2014) 'Leveraged Interests: Financial Industry Power and the Role of Private Sector Coalitions'. Review of International Political Economy, Vol. 1, No. 3, pp. 575-610.

Quaglia, L. (2012) 'The Regulatory Response of the European Union to the Global Financial Crisis'. In Mayntz, R. (ed.) Crisis and Control (Frankfurt (Main): Campus Verlag), 171-96.

Quaglia, L. (2013) 'Financial Services Governance in the European Union after the Global Financial Crisis: Incremental Change or Path-Breaking Reform'. In Moschella, M. and Tsingou, E. (eds) Great Expectations, Slow Transformation: Incremental Change in Post-Crisis Regulation (Colchester: ECPR Press), 57-72.

Steinlin, S. and Trampusch, C. (2012) 'Institutional Shrinkage: The Deviant Case of Swiss Banking Secrecy'. Regulation \& Governance, Vol. 6, No. 2, pp. 242-59.

Tait, N. (2011)'EU to Shake up Mortgage Rule', Financial Times, 31 March. Available online at: ft.com/intl/cms/s/0/86401b64-5aff-11e0-a290-00144feab49a.html?siteedition=intl\#axzz3Tt5eTNBR.

Tsingou, E. (2008) 'Transnational Private Governance and the Basel Process: Banking Regulation and Supervision, Private Interests and Basel II'. In Nölke, A. and Graz, J.-C. (eds) Transnational Private Governance and Its Limits (London: Routledge and ECPR), 58-68.

Tsingou, E. (2010) 'Regulatory Reaction to the Global Credit Crisis. Analyzing a Policy Community under Stress'. In Helleiner, E., Pagliari, S. and Zimmermann, H. (eds) Global Finance in Crisis. The Politics of International Regulatory Change (London: Routledge), 21-36.

Vzbw (2009) 'European Financial Supervision Response to the Commission's Communication of 27.05.2009', 15 July. Available online at: circabc.europa.eu. 
Woll, C. (2013) 'Lobbying under Pressure: The Effect of Salience on European Union Hedge Fund Regulation'. JCMS, Vol. 51, No. 3, pp. 555-72.

Woolley, J. T. and Ziegler, J. N. (2011) 'The Two-Tiered Politics of Financial Reform in the United States', Working Paper No. 111-11, Institute for Research on Labor and Employment, University of California.

Young, K.L. (2012) 'Transnational Regulatory Capture? An Empirical Examination of the Transnational Lobbying of the Basel Committee on Banking Supervision'. Review of International Political Economy, Vol. 19, No. 4, pp. 663-88.

Young, K.L. (2013) 'Financial Industry Groups Adaption to the Post-Crisis Regulatory Environment: Changing Approaches to the Policy Cycle'. Regulation \& Governance, Vol. 7, No. 4, pp. $460-80$.

Young, K.L. (2014) 'Losing Abroad but Winning at Home: European Financial Industry Groups in Global Financial Governance since the Crisis'. Journal of European Public Policy, Vol. 21, No. 3, pp. 367-88.

\section{List of Interviews}

Interview with NGO representative, London, 6 July 2011.

Interview with a financial industry lobbyists, Brussels, 13 May 2013.

Interview with financial industry representative, Brussels, 14 May 2013.

Interview with NGO representative, Brussels, 15 May 2013.

Interview with a consumer advocate, Brussels, 21 May 2013.

Interview, Brussels, 21 May 2013.

Interview with Commission official, Brussels, 21 May 2013.

Interview with industry representative, Brussels, 22 May 2013.

Interview with Commission official, Brussels, 22 May 2013.

Interview with a consumer advocate, Brussels, 1 June 2013.

Interview with a representative of an NGO, Brussels, 9 June 2011.

Interview with a financial industry lobbyist, London, 17 June 2013.

Interview with financial industry lobbyist, Brussels, 24 June 2013. 